\title{
PKM PENYUSUNAN MASTERPLAN PEMBANGUNAN SMART CITY KABUPATEN SIAK, PROVINSI RIAU
}

\author{
Winarno \\ Prodi Informatika, FTI, Universitas Multimedia Nusantara Jakarta \\ Email: pmwinarno@umn.ac.id
}

\begin{abstract}
Abstrak
Sejak tahun 2017 hingga kini tahun 2020, Kabupaten Siak telah melaksanakan program kerja terkait Smart City, dan telah dilakukan kegiatan Monitoring dan Evaluasi setiap tahun, baik secara Internal, maupun oleh Team Smart City Kementrian Kominfo. Smart city merupakan pendekatan yang relevan dalam melakukan pembangunan di Kabupaten Siak di Era Teknologi Informasi dan Komunikasi saat ini. Setiap Pusat Pemerintahan harus menerapkan konsep Smart City, dimana pemerintah memberikan pelayanan publik yang lebih cepat dan efisien, serta mendukung warganya dengan infrastruktur teknologi informasi dan komunikasi dalam berbagai kegiatan, baik dalam aspek kehidupan, sosial, ekonomi, lingkungan, maupun tata kota. Dalam Musrenbang nasional baru-baru ini, Presiden Jokowi menyampaikan bahwa fenomena kompetisi saat ini bukan lagi antar negara yang kuat dengan yang lemah, melainkan negara yang cepat dalam memberikan layanan mengalahkan negara yang lambat dalam memberikan layanan. Gerakan Mewujudkan 100 Smart City ini dimaksudkan sebagai koridor kolaborasi dengan memahami fenomena di atas. Kegiatan PKM yang dilakukan adalah melaksanakan penyusunan buku Masterplan Pembangunan Smart City di Kabupaten Siak, pada akhir 2020. Hasil dari kegiatan tersebut adalah tiga buah buku Masterplan Smart City Kabupaten Siak.
\end{abstract}

Kata Kunci : masterplan, smart city, kabupaten siak

\section{PENDAHULUAN}

Sejak tahun 2017 hingga kini tahun 2020, Kabupaten Siak telah melaksanakan program kerja terkait Smart City, dan telah dilakukan kegiatan Monitoring dan Evaluasi setiap tahun, baik secara Internal, maupun oleh Team Smart City Kementrian Kominfo.

Smart city merupakan pendekatan yang relevan dalam melakukan pembangunan di Kabupaten Siak di Era Teknologi Informasi dan Komunikasi saat ini. Setiap Pusat Pemerintahan harus menerapkan konsep Smart City, dimana pemerintah memberikan pelayanan publik yang lebih cepat dan efisien, serta mendukung warganya dengan infrastruktur teknologi informasi dan komunikasi dalam berbagai kegiatan, baik dalam aspek kehidupan, sosial, ekonomi, lingkungan, maupun tata kota. Dalam Musrenbang nasional baru-baru ini, Presiden Jokowi menyampaikan bahwa fenomena kompetisi saat ini bukan lagi antar negara yang kuat dengan yang lemah, melainkan negara yang cepat dalam memberikan layanan mengalahkan negara yang lambat dalam memberikan layanan. Gerakan Mewujudkan 100 
Smart City ini dimaksudkan sebagai koridor kolaborasi dengan memahami fenomena di atas.

Sebagai Kabupaten yang sudah terpilih melalui assessment yang cukup komprehensif, kami telah mendapatkan fasilitasi guna mengembangkan sendiri visi, strategi dan prioritas smart city kami dengan melihat potensi dan permasalahan, kesiapan infrastruktur, serta SDM yang kami miliki.

Pada saat Master Plan Smart City Kabupaten Siak ini disusun, sedang terjadi pandemi Virus Covid-19 (Corona Virus Disease 2019) di seluruh dunia, termasuk di Indonesia, sehingga banyak kegiatan di seluruh aspek kehidupan terganggu, dimana masyarakat diminta untuk tidak keluar rumah, dan disarankan bekerja dari rumah. Termasuk sekolah-sekolah juga ditutup, dan kegiatan belajar/mengajar dilakukan dari rumah.

Dengan adanya wabah Covid-19, maka kegiatan ekonomi, sosial menjadi lumpuh. Bahkan di bidang keagamaan, kegiatan berjamaah terpaksa tidak direkomendasikan, karena dikuatirkan menjadi sebab penularan wabah Covid.

Kami juga memahami bahwa mengembangkan smart city di Kabupaten Siak bukan berarti menjadikan teknologi informasi dan komunikasi serta solusi teknologi sebagai tujuan akhir - misalnya dengan membuat command center yang mewah namun miskin fungsi. Namun kami lebih fokus kepada inovasi dan terobosan untuk menyelesaikan masalah prioritas dan atau mengembangkan sektor unggulan di Kabupaten Siak, berbasis data yang terintegrasi, dan kolaboratif antar sektor. Dan yang lebih penting lagi, pembangunan berbasis smart city secara simultan harus bisa menghasilkan smart people dan smart society.

\section{METODE}

Dalam melaksanakan kegiatan PKM penyusunan buku Masterplan Pembangunan Smart City Kabupaten Siak, penulis ditunjuk sebagai Tanaga Ahli/Konsultan berdasarkan SK Bupati Siak No. 528/HK/KPTS/2020 tanggal 30 September 2020 tentang penunjukan tenaga ahli pengembangan smart city Kabupaten Siak.
Selanjutnya kegiatan yang dilaksanakan dalam penyusunan Buku 1 adalah meliputi (a) Analisis masa depan, (b) Analisis Kesiapan Kabupaten Siak sebagai smart city, (c) Analisis Kesenjangan Strategis Kabupaten Siak, (d) Analisis Visi dan Misi Smart City Kabupaten Siak, (e) Analisis Strategi Pembangunan Smart City Kabupaten Siak, (f) Analisis Kebutuhan Infrastruktur pendukung Smart City, dan (g) Analisis Kebutuhan aplikasi piranti lunak pendukung smart city, (h) pengumpulan data pembangunan jangka menengah dari Bappeda Kabupaten Siak, (i) Pengumpulan data Rencana Anggaran Pembangunan Daerah Kabupaten Siak tahun 2020 terkait teknologi informasi, (j) Pengumpulan Usulan Pengembangan Aplikasi Smart City dari Dinas-dinas/Badan serta Kecamatan-kecamatan, (k) Focus Group Discussion di Kabupaten Siak yang dihadiri oleh para Kepala Dinas dan Camat, serta pimpinan perusahaan di Kabupaten Siak, serta tokoh masyarakat, (l) Pembuatan Draft buku Masterplan Smart City dan buku final Masterplan Smart City Kabupaten Siak. Untuk selanjutnya buku tersebut disyahkan dengan SK Bupati Kabupaten Siak sebagai Dokumen Resmi tentang Pembangunan Smart City Kabupaten Siak.

\section{HASIL DAN PEMBAHASAN}

\section{Analisis Masa Depan}

Dari kegiatan analisis masa depan, maka diperoleh isyu-isyu tentang pertumbuhan kota-kota yang berlangsung secara liar (tidak tertata dan kumuh), perilaku masyarakat yang tidak sabaran, pekerjaan yang semakin menumpuk, pengambilan keputusan harus menggunakan data agar akurat, dunia yang menjadi semakin sempit, fenomena urbanisasi, bisnis yang berlangsung secara digital (bricks and clicks), pentingnya pembangunan infrastruktur di masa depan, gerakan penghijauan baru, inovasi terus-menerus, kesehatan kebugaran dan kesejahteraan (health, well being), trend sosial (generation $\mathrm{X}, \mathrm{Y}, \mathrm{Z}$ dan she-economy), masa depan energi, masa depan mobilitas, konektivitas dan konvergensi, ekonomi diluar batu bata, model bisnis baru dan teknologi internet of things. 


\section{Analisis Kesiapan Kabupaten Siak Sebagai Smart City}

Dari kegiatan analisis kesiapan Kabupaten Siak sebagai Smart City, maka diperoleh analisis kesiapan struktur, infrastruktur dan suprastruktur.

Kesiapan struktur mencakup analisis sumberdaya manusia, sumberdaya pemerintahan (aparat sipil negara), serta analisis kapasitas keuangan Kabupaten Siak.

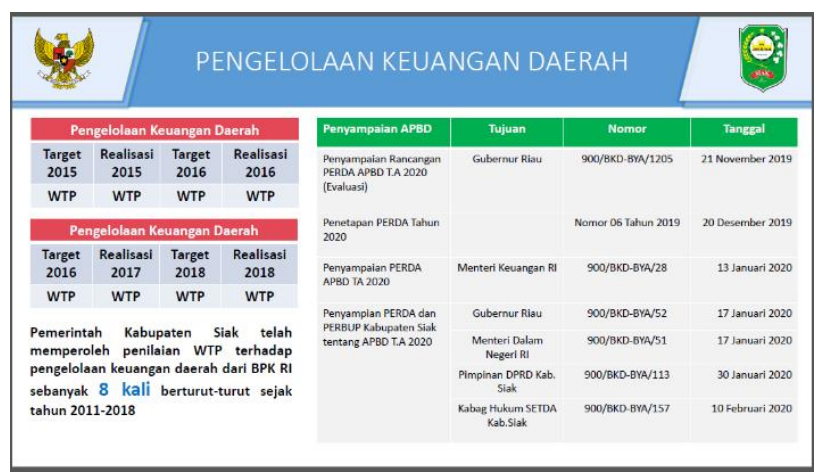

Gambar 1. Profil Pengelolaan Keuangan Kabupaten Siak.

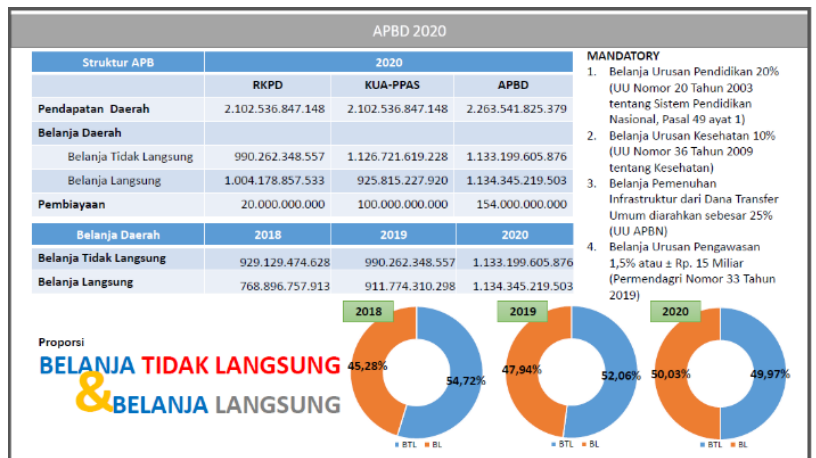

Gambar 2. APBD Kabupaten Siak 2020

Analisis kesiapan infrastruktur Kabupaten Siak mencakup kesiapan infrastruktur fisik, infrastruktur digital, dan infrastruktur sosial.

Analisis kesiapan suprastruktur Kabupaten Siak meliputi kesiapan peraturan/kebijakan di Kabupaten Siak terkait dengan Smart City, Peraturan daerah, dan kesiapan kelembagaan di Kabupaen Siak.

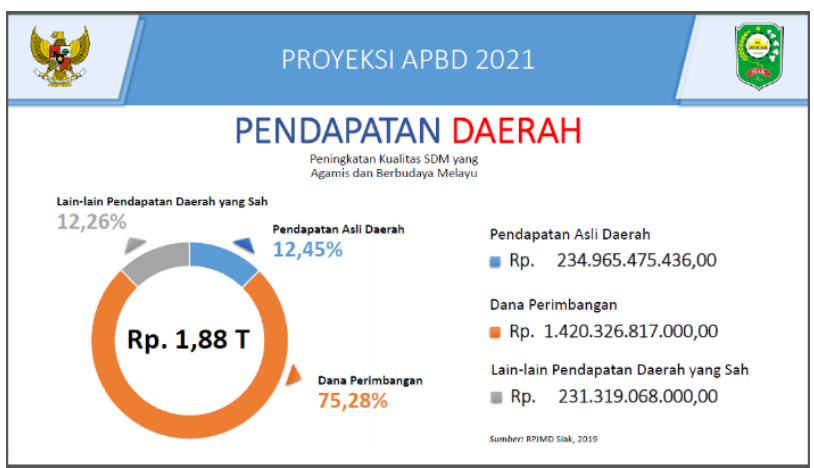

Gambar 2.4. Proyeksi APBD Kabupaten Siak 2021 (Aspek Pendapatan Daerah)

Tabel 1. Analisis Kesiapan Infrastruktur Fisik Kabupaten Siak

\begin{tabular}{|c|c|c|c|c|c|}
\hline \multirow[t]{2}{*}{ No } & \multirow[t]{2}{*}{ Komponen } & \multirow[t]{2}{*}{ Jumlah } & \multicolumn{3}{|c|}{ Interpretasi } \\
\hline & & & Baik & Sedang & Buruk \\
\hline 1 & $\begin{array}{l}\text { Persentase } \\
\text { jalan } \\
\text { kabupaten/ko } \\
\text { ta dalam } \\
\text { kondisi baik }\end{array}$ & $\begin{array}{c}\frac{964,01}{2880,19} \times \\
100 \% \\
=33.47 \%\end{array}$ & $\sqrt{ }$ & & \\
\hline 2 & $\begin{array}{l}\text { Persentase } \\
\text { panjang } \\
\text { pedestrian } \\
\text { (fasilitas } \\
\text { pejalan kaki) } \\
\text { per panjang } \\
\text { jalan } \\
\text { beraspal }\end{array}$ & $\begin{array}{c}\frac{15,97}{827,87} x \\
100 \% \\
=1.93 \%\end{array}$ & $\sqrt{ }$ & & \\
\hline 3 & $\begin{array}{l}\text { Persentase } \\
\text { lampu jalan } \\
\text { yang } \\
\text { berfungsi } \\
\text { dengan baik }\end{array}$ & 622 & $\sqrt{ }$ & & \\
\hline 4 & $\begin{array}{l}\text { Persentase } \\
\text { rambu dan } \\
\text { petunjuk } \\
\text { jalan dalam } \\
\text { kondisi baik }\end{array}$ & $\begin{array}{l}\frac{1,770}{2,150} x \\
100 \% \\
=82 \%\end{array}$ & & & \\
\hline 5 & $\begin{array}{l}\text { Adanya } \\
\text { kawasan } \\
\text { perkantoran } \\
\text { untuk } \\
\text { kegiatan } \\
\text { bisnis }\end{array}$ & 5 & $\sqrt{ }$ & & \\
\hline
\end{tabular}




\begin{tabular}{|l|l|l|l|l|}
\hline $\mathbf{6}$ & $\begin{array}{l}\text { Adanya } \\
\text { kawasan } \\
\text { perbelanjaan } \\
\text { untuk } \\
\text { kegiatan } \\
\text { perdagangan } \\
\text { masyarakat }\end{array}$ & & & \\
\hline $\mathbf{7}$ & $\begin{array}{l}\text { Persentase } \\
\text { sarana } \\
\text { prasarana } \\
\text { pendidikan } \\
\text { dalam } \\
\text { kondisi baik }\end{array}$ & $43,37 \%$ & $\sqrt{ }$ & \\
\hline $\mathbf{8}$ & & & \\
\hline $\begin{array}{l}\text { Persentase } \\
\text { sarana } \\
\text { prasarana } \\
\text { pelayanan } \\
\text { kesehatan } \\
\text { dalam } \\
\text { kondisi baik }\end{array}$ & $100 \%$ & $\sqrt{ }$ & \\
\hline
\end{tabular}

\section{Analisis Kesenjangan Strategis Smart City Kabupaten Siak}

masa depan, maka diperoleh isyu-isyu tentang pertumbuhan kota-kota yang berlangsung secara liar (tidak tertata dan kumuh), perilaku masyarakat yang tidak sabaran, pekerjaan yang semakin menumpuk, pengambilan keputusan harus menggunakan data agar akurat,

Tabel 2. Analisis kesenjangan antara kondisi masa depan dan kondisi saat ini

\begin{tabular}{|c|l|l|l|}
\hline No & $\begin{array}{c}\text { Kondisi } \\
\text { Masa Yang } \\
\text { Akan } \\
\text { Datang }\end{array}$ & $\begin{array}{c}\text { Kondisi } \\
\text { Saat Ini } \\
\text { As is }\end{array}$ & $\begin{array}{c}\text { Strategy, } \\
\text { Program Kerja } \\
\text { dan Langkah } \\
\text { Aksi }\end{array}$ \\
\hline $\mathbf{1}$ & $\begin{array}{l}\text { Smart } \\
\text { Governance }\end{array}$ & & \\
& $\begin{array}{l}\text { Pemerintah } \\
\text { menerapkan } \\
\text { sistem } \\
\text { administrasi } \\
\text { pemerintahan } \\
\text { yang cerdas }\end{array}$ & $\begin{array}{l}\text { Belum } \\
\text { sepenuhnya } \\
\text { cerdas }\end{array}$ & $\begin{array}{l}\text { Mengembangkan } \\
\text { aplikas e-Gov } \\
\text { sesuai dengan } \\
\text { OPD masing } \\
\text { masing }\end{array}$ \\
\hline $\mathbf{2}$ & $\begin{array}{l}\text { Smart } \\
\text { Branding }\end{array}$ & & \\
& & & \\
\hline
\end{tabular}

\begin{tabular}{|c|c|c|}
\hline $\begin{array}{l}\text { Menjadi } \\
\text { destinasi } \\
\text { wisata } \\
\text { unggulan di } \\
\text { Sumatera, } \\
\text { adanya } \\
\text { obyek } \\
\text { wisata, paket } \\
\text { wisata, } \\
\text { adanya } \\
\text { operator } \\
\text { Turism, } \\
\text { akomodasi } \\
\text { perhotelan, } \\
\text { restoran, } \\
\text { travel, dan } \\
\text { atitude } \\
\text { masyarakat } \\
\text { yang bagus } \\
\text { terhadap } \\
\text { wisatawan. } \\
\text { Kuliner Khas } \\
\text { yang sudah } \\
\text { dikemas } \\
\text { dengan baik. }\end{array}$ & $\begin{array}{l}\text { Hotel minim. } \\
\text { Belum adanya } \\
\text { oporator } \\
\text { turism } \\
\text { Obyek wisata } \\
\text { sudah rapih, } \\
\text { peta obyek } \\
\text { wisata belum } \\
\text { cukup, } \\
\text { restoran } \\
\text { sekitar obyek } \\
\text { wisata belum } \\
\text { bagus, } \\
\text { atitude } \\
\text { masyarakat } \\
\text { sudah ramah. } \\
\text { Kuliner } \\
\text { Belum } \\
\text { dikemas } \\
\text { dengan baik. }\end{array}$ & $\begin{array}{l}\text { Menambah } \\
\text { perhotelan. } \\
\text { Menambah } \\
\text { restoran } \\
\text { (memperbaiki } \\
\text { restoran yang } \\
\text { ada) } \\
\text { Menambah peta } \\
\text { wisata } \\
\text { Jalan yang bagus } \\
\text { dikemas dengan } \\
\text { baik. } \\
\text { Mengembangkan } \\
\text { Aplikasi } \\
\text { Kepariwisataan. }\end{array}$ \\
\hline
\end{tabular}




\begin{tabular}{|c|c|c|c|}
\hline \multirow[t]{2}{*}{5} & $\begin{array}{l}\text { Smart } \\
\text { Society }\end{array}$ & & \\
\hline & $\begin{array}{l}\text { Kota yang } \\
\text { aman. } \\
\text { Interaksi } \\
\text { masyarakat } \\
\text { yang positif. } \\
\text { Masyarakat } \\
\text { yang mudah } \\
\text { dalam } \\
\text { pembelajaran } \\
\text { melalui e- } \\
\text { learning. }\end{array}$ & $\begin{array}{l}\text { Masyarakat } \\
\text { belum kritis } \\
\text { menggunakan } \\
\text { media sosial. } \\
\text { Sistem e- } \\
\text { learning } \\
\text { belum } \\
\text { diterapkan. }\end{array}$ & $\begin{array}{l}\text { Memajukan sikap } \\
\text { positif } \\
\text { masyarakat dalam } \\
\text { media sosial dan } \\
\text { menerapkan e- } \\
\text { learning }\end{array}$ \\
\hline \multirow[t]{2}{*}{6} & $\begin{array}{l}\text { Smart } \\
\text { Enviroment }\end{array}$ & & \\
\hline & $\begin{array}{l}\text { Lingkungan } \\
\text { yang bersih, } \\
\text { asri, tertata } \\
\text { rapih. } \\
\text { Pengelolaan } \\
\text { sampah yang } \\
\text { baik. } \\
\text { Pengelolaan } \\
\text { energy yang } \\
\text { baik. }\end{array}$ & $\begin{array}{l}\text { Sudah baik } \\
\text { tapi perlu } \\
\text { ditingkatkan. }\end{array}$ & $\begin{array}{l}\text { Komunitas } \\
\text { Perempuan Peduli } \\
\text { sampah/ Bank } \\
\text { Sampah. } \\
\text { Masyarakat } \\
\text { peduli api. } \\
\text { Masyarakat } \\
\text { hemat energy. }\end{array}$ \\
\hline
\end{tabular}

Gambar 1. (TNR 11, before 6 pt, after 12 pt)

\section{Analisis Visi dan Misi Smart City Kabupaten Siak}

Bagian ini bertujuan untuk menjelaskan dan menguraikan visi dan misi smart city Kabupaten Siak sebagai landasan perumusan rumusan sasaran target capaian pembangunan smart city di Kabupaten Siak. Visi dan misi smart city Kabupaten Siak memperhatikan beberapa hal, yaitu: (1) Visi dan Misi Pembangunan Daerah yang tercantum di dalam dokumen perencanaan pembangunan Kabupaten Siak, yaitu RPJP Kabupaten Siak dan RPJM Kabupaten Siak; (2) Visi dan Misi Pembangunan Nasional; (3) Harapan warga masyarakat; dan (4) Analisis Faktor eksternal di masa depan;
Untuk menyusun sebuah visi smart city Kabupaten Siak, terdapat kriteria suatu rumusan visi smart city, yaitu sebagai berikut: (1) Menggambarkan arah yang jelas tentang kondisi masa depan yang ingin dicapai dalam 5 (lima) hingga 10 (sepuluh) tahun mendatang (clarity of direction); (2) Menjawab permasalahan pembangunan smart city Kabupaten Siak dan/atau isu strategis yang perlu diselesaikan dalam jangka pendek, jangka menengah dan jangka panjang; (3) Disertai dengan penjelasan yang lebih operasional sehingga mudah dijadikan acuan bagi perumusan kebijakan, strategi dan program (articulative); (4) Disertai penjelasan mengapa visi smart city tersebut dibutuhkan di Kabupaten Siak, relevansi visi dengan permasalahan dan potensi pembangunan di Kabupaten Siak; dan (5) Sejalan dengan visi dan arah pembangunan Kabupaten Siak dan nasional.

Sedangkan syarat sebuah visi yang baik adalah: (1) Imaginable, dapat dibayangkan oleh semua stakeholders; (2) Desirable, memiliki nilai yang memang diinginkan dan dicita-citakan; (3) Feasible, Memungkinkan, wajar dan layak untuk dicapai dengan situasi, kondisi dan kapasitas yang ada; (4) Focussed, memusatkan perhatian kepada isu dan permasalahan utama daerah, sehingga pemerintahan dan pembangunan Kabupaten Siak dapat beroperasi dan terselenggara secara efektif, efisien dan berkelanjutan serta dapat terjamin eksistensi daerah dimasa depan; (5) Flexible, dapat mengantisipasi dan disesuaikan dengan perubahan zaman; (6) Communicable, dapat dikomunikasikan dan mudah dimengerti semua pelaku; dan (7) Incisive, dapat dirumuskan dan ditulis dengan suatu pernyataan yang tajam, singkat, jelas dan padat.

Setelah pernyataan visi smart city daerah tersusun, tahapan selanjutnya adalah menerjemahkan visi smart city tersebut ke dalam ukuran capaian keberhasilan yang disusun di dalam sasaran smart city Kabupaten Siak. Sasaran smart city Kabupaten Siak merupakan rangkaian indikator keberhasilan yang menjadi alat ukur dalam evaluasi pelaksanaan smart city. Sebuah sasaran smart city daerah yang baik, harus memenuhi kritesia sebagai berikut: (1) . Specific, yaitu definisi indikator kinerja smart city harus jelas dan tidak bermakna ganda sehingga mudah untuk dimengerti dan digunakan; (2) Measurable, yaitu indikator yang 
digunakan dapat diukur dengan skala penilaian tertentu yang disepakati, dapat berupa pengukuran secara kuantitas, kualitas atau harga. (3) Approriate, yaitu indikator yang dipilih harus sesuai dengan upaya peningkatan pelayanan/kinerja. (4) Relevant, yaitu indikator terkait secara logis dengan visi smart city yang diinginkan serta tugas dan fungsi masingmasing institusi yang bertanggung jawab; (5) Continously improved, yaitu terdapat peningkatan kinerja seiring dengan terlaksananya programprogram smart city; (6) 6. Cost-effective, manfaat target capaian kinerja smart city yang diinginkan sebanding atau dapat dicapai dengan biaya yang harus dialokasikan.

Berdasarkan kriteria di atas, maka dirumuskan Visi Smart City Kabupaten Siak sbb: Terwujudnya Kabupaten Siak sebagai Smart City yang mendukung tercapainya Visi Jangka Panjang Pembangunan Kabupaten Siak yang disertai penerapan smart government, smart branding, smart economy, smart living, smart society, dan smart environment pada tahun 2022.

Dan Misi Smart City Kabupaten Siak adalah sebagai berikut: (1) Mewujudkan tata kelola dan tata pamong pemerintahan daerah yang efektif, efisien, komunikatif; (2) Meningkatkan daya saing daerah dengan penataan wajah kota dan pemasaran potensi daerah; (3) Mewujudkan ekosistem yang mendukung aktifitas ekonomi masyarakat yang selaras dengan sektor ekonomi unggulan daerah; (4) Mewujudkan lingkungan tempat tinggal yang layak tinggal, nyaman, dan efisien; (5) Mewujudkan ekosistem sosio-teknis masyarakat yang humanis dan dinamis; dan (6) Mewujudkan tata kelola lingkungan hidup yang baik, bertanggung-jawab, dan berkelanjutan.

\section{Analisis Strategis Pembangunan Smart City}

Dalam perencanaan $\begin{array}{r}\text { strategis } \\ \text { pengembangan Smart City diperlukan }\end{array}$
metodologi untuk menentukan langkah langkah
strategis apa yang perlu diambil agar tujuan
pengembangan Smart City dapat tercapai. Salah
satu metodologi yang cukup umum digunakan
untuk berbagai jenis perencanaan strategis
adalah Analisis SWOT. Analisis SWOT adalah
metode yang digunakan untuk mengevaluasi 4

(empat) aspek yaitu kekuatan (strengths), kelemahan (weaknesses), peluang (opportunities), dan ancaman (threats) dalam suatu program kerja atau proyek. Keempat aspek itulah yang membentuk akronim SWOT (strengths, weaknesses, opportunities, dan threats). Proses ini mengidentifikasi faktor internal dan eksternal yang mendukung maupun yang tidak dalam mencapai tujuan program kerja atau proyek dimaksud. Analisis SWOT diterapkan dengan cara menganalisis keempat faktor SWOT. Langkah selanjutnya adalah menetapkan langkah langkah strategis dimana kekuatan (strengths) mampu memanfaatkan peluang (opportunities) yang ada, di samping itu bagaimana cara mengatasi kelemahan (weaknesses) yang diidentifikasi. Selanjutnya menetapkan langkah strategis untuk menghadapi atau mengatasi ancaman (threats) yang ada, sedapat mungkin dengan menggunakan kekuatan yang dimiliki.

\section{a. Kekuatan}

Kekuatan adalah kondisi internal yang menjadi pendorong keberhasilan meraih sukses dalam program kerja atau proyek Smart City. Menentukan kekuatan harus dilakukan secara obyektif agar dapat benar benar menghasilkan strategi yang realistis dan tepat. Kekuatan dapat berupa kepemilikan atau akses terhadap sumber daya yang diperlukan termasuk sumber daya manusia, sumber daya keuangan, teknologi dan lain lain. Kekuatan juga dapat berupa pengalaman, kebijakan yang sudah dirumuskan dan secara konsisten diterapkan dan hal hal lain. Perlu diingatkan sekali lagi bahwa kekuatan umumnya adalah sesuatu yang bersifat internal, dalam hal ini pada pemerintah daerah.

\section{b. Kelemahan}

Kelemahan adalah kondisi internal yang berpotensi menjadi hambatan dalam mencapai tujuan pengembangan Smart City

Ekonomi, Sosial, dan Budaya 
atau bagian dari pengembangan Smart City. Hal yang tidak menjadi kekuatan sejatinya adalah kelemahan. Demikian juga strategi yang baik adalah melakukan upaya yang tepat sehingga kelemahan dapat dikurangi agar pada satu saat menjadi kekuatan. Kelemahan dapat berupa tidak tersedianya hal hal yang diperlukan seperti kebijakan, kompetensi SDM, sumber pendanaan, infrastruktur dasar. Hal hal lain seperti resistensi terhadap inovasi dan perubahan, rendahnya disiplin dan ketertiban umum dan rendahnya literasi masyarakat dapat juga menjadi kelemahan yang bila tidak ditanggulangi dapat menghambat tercapainya sasaran pengembangan Smart City.

\section{c. Peluang}

Peluang secara umum dapat dikenali sebagai kondisi eksternal yang menjadi pendorong keberhasilan mengembangkan atau mewujudkan Smart City. Peluang ini dapat berbentuk minat investasi, pertumbuhan ekonomi, meningkatnya kesejahteraan, pergantian generasi, dukungan pemerintah pusat, peran serta masyarakat, potensi kontribusi dari sektor usaha. Mempertemukan kekuatan dengan peluang yang dimiliki berpotensi menjadi langkah strategis yang penting.

\section{d. Ancaman}

Ancaman adalah kondisi eksternal yang berpotensi menghambat pencapaian tujuan pengembangan Smart City. Kondisi ini umumnya sulit untuk diatasi atau dikendalikan sepenuhnya. Yang dapat dilakukan adalah mengurangi dampak dari kondisi ini melalui mitigasi dan menghindari strategi yang memerlukan kondisi yang justru menjadi ancaman. Yang berpotensi menjadi ancaman bisa berupa hal hal seperti perubahan iklim, bencana alam, gejolak sosial di masyarakat, konflik antar masyarakat, gangguan ketertiban umum dan lain lain. Selain itu dalam penerapan teknologi sebagai bagian dari inovasi dalam pengembangan Smart City juga dapat ditemukan ancaman seperti ketergantung berlebihan pada pelaku usaha dan teknologi tertentu, ketertinggalan teknologi yang berkembang/berubah cepat, meningkatnya biaya lisensi dan biaya perawatan teknologi tertentu. Pemahaman akan ancaman dapat sangat berguna dalam menentukan langkah langkah strategis apa yang akan diambil dalam pengembangan Smart City dengan risiko yang minimal yang mampu dikelola dengan baik.

\begin{tabular}{|c|c|c|}
\hline $\begin{array}{r}\text { Faktor Eksternal Internal } \\
\text { S dan W } \\
\text { O dan T }\end{array}$ & $\begin{array}{c}\text { Kekuatan } \\
\text { 1. } \begin{array}{c}\text { Terdapat } \\
\text { pemerintahan dengan } \\
\text { kompetensi yang } \\
\text { tinggi }\end{array}\end{array}$ & $\begin{array}{c}\text { Kelemahan } \\
\text { 2. Jumlah SDM pemerintahan } \\
\text { sedikit }\end{array}$ \\
\hline $\begin{array}{c}\text { Peluang } \\
\text { 1. Terdapat perguruan } \\
\text { tinggi di daerah }\end{array}$ & $\begin{array}{c}\text { SDM di dalam pemerintahan } \\
\text { berkolaborasi dengan } \\
\text { perguruan tinggi untuk } \\
\text { menyusun inovasi tata kelola } \\
\text { smart city }\end{array}$ & $\begin{array}{c}\text { Bekerja sama dengan } \\
\text { perguruan tinggi untuk } \\
\text { membantu kekurang SDM di } \\
\text { pemerintahan }\end{array}$ \\
\hline $\begin{array}{c}\text { Ancaman } \\
\text { 2. Brain drain (banyaknya SDM } \\
\text { lokal berkualitas yang bekerja } \\
\text { di luar daerah) }\end{array}$ & $\begin{array}{c}\text { Pemberdayaan SDM lokal } \\
\text { yang berkualitas oleh SDM- } \\
\text { SDM pemerintahan }\end{array}$ & $\begin{array}{c}\text { Mendorong penggunaan SDM } \\
\text { pekerja lepas untuk } \\
\text { mengatasi kekurangan SDM } \\
\text { berkualitas }\end{array}$ \\
\hline
\end{tabular}

Gambar 5. Contoh Analisis SWOT Smart Governance

\section{Analisis Kebutuhan Infrastruktur Pendukung Smart City}

Kebutuhan Infrastruktur dalam mendukung smart city dalam hal ini yang dimaksud adalah infrastruktur TIK (teknologi informasi dan komunikasi). Beberapa kebutuhan utama yang perlu tersedia agar smart city terbangun adalah: (1) Tersedianya Jaringan komputer (network) perkotaan; (2) Tersedianya NOC (network operation center) dan atau Pusat Data (data center); (3) Tersedianya Ruang Kendali (City Operation Center/COC) yang terintegrasi dengan aplikasi ruang kendali dan aplikasi sensing, baik camera pengawasan (CCTV) maupun perangkat sensor lainnya yang tersebar di area kota. 


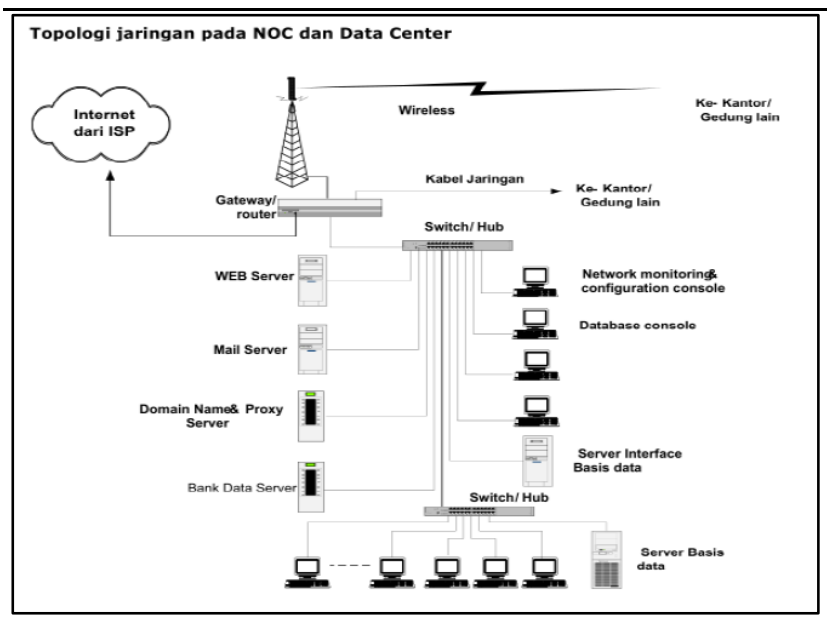

Gambar 6. Contoh ilustrasi contoh arsitektur Data Center dan NOC

\section{KESIMPULAN}

Kesimpulan yang dapat ditarik dari kegiatan PKM ini adalah bahwa penyusunan Buku 1 Masterplan Pembangunan Smart City Kabupaten Siak telah dapat dilaksanakan dengan baik. Selain itu, buku tersebut telah digunakan sebagai Dokumen Pembangunan di Kabupaten Siak

\section{UCAPAN TERIMAKASIH}

Ucapan terimakasih disampaikan kepada Pemerintah Kabupaten Siak, c.q. Dinas Kominfo Statistika dan Sandi atas penugasan sebagai Tenaga Ahli dalam penyusunan Buku Masterplan Pembangunan Smart City Kabupaten Siak, dengan SK Bupati No. 528/HK/KPTS/2020 tanggal 30 September 2020 tentang penunjukan tenaga ahli pengembangan smart city Kabupaten Siak.

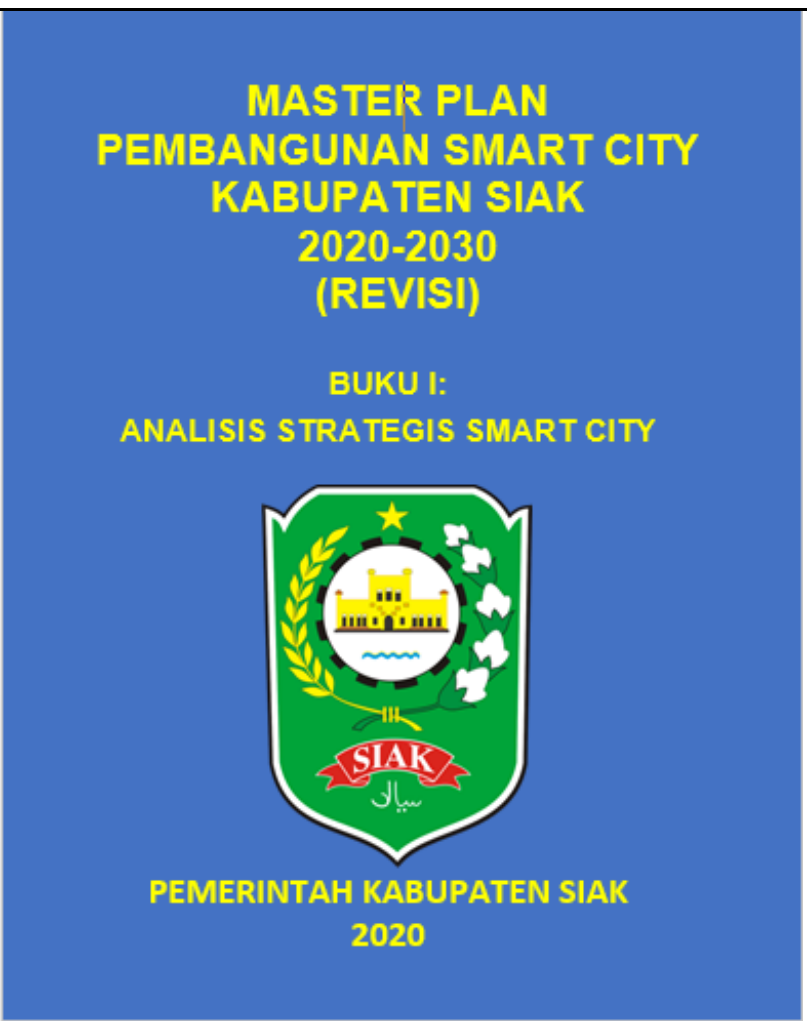

Gambar 7. Sampul Buku Masterplan Pembangunan Smart City Kabupaten Siak 2017-2027.

\section{REFERENSI}

Buku Panduan Penyusunan Masterplan Smart City, Gerakan Menujy 100 Smart City, (2017), Dirjen Aplikasi Informatika, Kemenkominfo RI

CFDS (Center for Digital Society) dan Kemendagri, Membangun Kota dan Kabupaten Pintar: Sebuah Panduan bagi Pemerintah Daerah, 2017

CitiasiaInc., Indikator-Indikator Smart City, 2017.

GERAKAN MENUJU 100 SMART CITY: Membangun Daya Saing Daerah Melalui Teknologi Informasi dan Komunikasi, Dirjen Aplikasi Informatika, Kemenkominfo RI, 2017 
PARASATI HAYU, KEBIJAKAN DAN RENCANA PENGEMBANGAN SMART CITY: "Menuju Pembangunan Perkotaan Berkelanjutan", (2017), Direktorat Perkotaan, Perumahan dan Permukiman, Kementerian
Perencanaan Pembangunan Nasional, Badan Perencanaan Pembangunan Nasional,

Subkhan Farid, New Indonesia, Dari Smart City Menuju Smart Nation, (2016), Elexmedia, 